\title{
Methane oxidising bacteria to upcycle effluent streams from anaerobic digestion of municipal biowaste
}

Tsapekos, Panagiotis; Khoshnevisan, Benyamin; Zhu, Xinyu; Zha, Xiao; Angelidaki, Irini

Published in:

Journal of Environmental Management

Link to article, DOI:

10.1016/j.jenvman.2019.109590

Publication date:

2019

Document Version

Peer reviewed version

Link back to DTU Orbit

Citation (APA):

Tsapekos, P., Khoshnevisan, B., Zhu, X., Zha, X., \& Angelidaki, I. (2019). Methane oxidising bacteria to upcycle effluent streams from anaerobic digestion of municipal biowaste. Journal of Environmental Management, 251, [109590]. https://doi.org/10.1016/j.jenvman.2019.109590

\section{General rights}

Copyright and moral rights for the publications made accessible in the public portal are retained by the authors and/or other copyright owners and it is a condition of accessing publications that users recognise and abide by the legal requirements associated with these rights.

- Users may download and print one copy of any publication from the public portal for the purpose of private study or research.

- You may not further distribute the material or use it for any profit-making activity or commercial gain

- You may freely distribute the URL identifying the publication in the public portal 


\section{Methane oxidising bacteria to upcycle effluent streams from anaerobic digestion of municipal biowaste}

Panagiotis Tsapekos $^{\mathrm{a}}$, Benyamin Khoshnevisan ${ }^{\mathrm{a}, \mathrm{b}}$, Xinyu Zhu ${ }^{\mathrm{a}}$, Xiao Zha ${ }^{\mathrm{a}, \mathrm{c}}$, Irini Angelidaki ${ }^{\mathrm{a}, *}$

aDepartment of Environmental Engineering, Technical University of Denmark, Kgs. Lyngby, DK-2800, Denmark

${ }^{b}$ Department of Mechanical Engineering of Agricultural Machinery, Faculty of Agricultural Engineering and Technology, College of Agriculture and Natural Resources, University of Tehran

${ }^{\mathrm{c}}$ School of Energy and Environment, Southeast University, No. 2 Sipailou Road, Nanjing, 210096, China

* Corresponding author: Irini Angelidaki, Department of Environmental Engineering, Technical University of Denmark, Bld 115, 2800 Lyngby, Denmark.

E-mail address: iria@env.dtu.dk, Tel.: +45 45251429 


\begin{abstract}
Conventional microbial protein production relies on the usage of pure chemicals and gases. Natural gas, which is a fossil resource, is the common input gas for bacterial protein production. Alternative sources for gas feedstock and nutrients can sufficiently decrease the operational cost and environmental impact of microbial protein production processes. In the present study, the effluents streams of municipal biowaste anaerobic digestion, were used to grow methane oxidising bacteria which can be used as protein source. Results demonstrated that a 40:60 $\mathrm{CH}_{4}: \mathrm{O}_{2}(\mathrm{v} / \mathrm{v}) \mathrm{gas}$ feeding resulted in microbial biomass production of $0.95 \mathrm{~g}-\mathrm{DM} / \mathrm{L}$ by a Methylophilus dominated community. When raw biogas was used as input for methane corresponding to the same initial methane partial pressure as before, instead of pure methane, the growth was partially hindered $(0.61$ $\mathrm{g}-\mathrm{DM} / \mathrm{L})$ due to the presence of $\mathrm{H}_{2} \mathrm{~S}\left(\mathrm{IC}_{50}: 1376 \mathrm{ppm}\right)$. Hence, desulfurization is suggested before using biogas for microbial protein production. At semi-continuous mode, results showed that the produced biomass had relatively high protein content ( $>40 \%$ of dry weight) and the essential amino acids lysine, valine, leucine and histidine were detected at high levels.
\end{abstract}

\title{
Keywords
}

Methanotrophs; mixed culture; municipal biowaste; digestate; 16S rRNA

\section{Introduction}

The rapid growth of humanity, projected to exceed 9 billion in 2050, intensifies the need of producing enough and high quality protein for the increased population. Aligned with "Goal 2: Zero Hunger" of the 17 sustainable development goals, it is an imperative need to secure food availability in order to avoid malnourished population (UNG Assembly, 2015). On this concept, finding sustainable alternative food and animal feed -that indirectly produces food -is of high importance. 
Traditionally, a significant share of agricultural land is devoted for grazing and/or crop production as animal feed. However, growing crops at fertile land stands as an energy drain because only a minor fraction of calories consumed by the livestock appears in the final product (Foley et al., 2011). To tackle the forthcoming nutritional scarcity, alternative sources of protein for animal feed should be explored. In this context, microbial protein produced through methane-fed aerobic fermentation has unique advantages and can be used as animal feed. Methanotrophs are a potential protein rich biomass ( $>75 \%$ of dry weight) and capable of substituting plant protein obtained from the conventional agriculture (Ritala et al., 2017). More specifically, methanotrophs use methane as their sole energy source while they assimilate different forms of nitrogen (i.e., nitrate, ammonium, and ammonia) in their proteinaceous cells (Strong et al., 2015).

Among methanotrophs, Methylococcus capsulatus is hitherto considered as the most representative species for feed cultivation as advised by its high amino acid profile (Strong et al., 2015). In a recent study, cultivation of $M$. capsulatus in potato wastewater, as ammonia and micronutrients source, led to production of biomass consisting of $45 \%$ protein and amino acid profile similar to the conventional animal feed (Rasouli et al., 2018). Despite the promising results, the use of pure strains for microbial protein production markedly increases the contamination risk and failure in efficient proteinaceous biomass production.

Opposite to pure cultures, mixed bacterial communities are more robust and can be more efficient in methane conversion leading to higher yields. In addition, they do not require strictly sterile conditions, which make them industrially interesting due to the reduced operational costs. However, the commercial microbial protein production attempted by biotechnology companies (e.g. Calysta Inc., UNIBIO) is based on cultures that require relatively pure source of influents streams to eliminate contamination risks. Nevertheless, operational costs to supply natural gas as methane source, and micro- (e.g. Copper) and macro-nutrients (e.g. Nitrogen) of chemical grade, are the 
bottlenecks to succeed in a low cost process. Moreover, use of natural gas as methane source, is not contributing to reduction of usage of fossil resources. Hence, at industrial-scale the sustainability of methane-based biocatalysis is debated (Kalyuzhnaya et al., 2013).

Inexpensive sources of both methane and nutrients are needed in order to ensure process sustainability and settle the bacterial protein production to roar. On this topic, the liquid and gas streams of anaerobic digestion (AD) process can serve as a solution. Firstly, the liquid stream of the $\mathrm{AD}$ process is traditionally used as fertilizer in order to provide trace elements and ammonium to the plants (Haraldsen et al., 2011). However, the storage and application of digestate on farmlands would result in fugitive emissions of methane $\left(\mathrm{CH}_{4}\right)$ and ammonia $\left(\mathrm{NH}_{3}\right)$, contributing toward global warming, acidification and eutrophication (Rafiee et al., 2016; Styles et al., 2018). Moreover, the largest part of nutrients contained in digestate are not captured by the plants; as the losses can surpass $50 \%$ of the initial nitrogen content (Matassa et al., 2015). On the contrary, the fixation of nutrients to produce protein-rich biomass appears to be promising alternative (Matassa et al., 2015). Secondly, the traditional practice to use biogas for combined heat and power generation could be economically unfavourable due to the implementation of various economic policy instruments (Lantz, 2012). Hence, an efficient microbial production using both liquid and gas streams will upgrade the economic value of two underutilized products. However, this 2nd generation production concept is not yet developed. Questions can rise about the quality of the microbial protein and whether can substitute the traditional sources of animal feeding (e.g. soybean and fishmeal).

The major objective of this study was to develop and elucidate the integration of gas and liquid streams of biogas process for microbial protein production. The primary aim was to define the optimal methane to oxygen ratio for growing mixed methanotrophic culture on biologically produced digestate and methane. In this regard, gas composition significantly influences the growth 
of methanotrophic cultures (Cantera et al., 2016). Subsequently, the fermentation process was conducted at semi-continuous operation at optimized conditions. The microbial composition of the mixed culture was revealed and the produced protein was evaluated based on the amino acid profile.

\section{Materials and methods}

\subsection{Methane oxidizing bacteria seed}

The mixed methanotrophic culture was collected from a chemostat lab-scale fermenter fed with pure gases (i.e. methane and oxygen) supplied by Air Liquide A/S (Taastrup, Denmark) and chemicals of analytical grade from Sigma-Aldrich ApS (Brøndby, Denmark). To start growing seed, sterilized batch bottles of total and working volume of 250 and $100 \mathrm{~mL}$, respectively, were filled with $3 \%(\mathrm{v} / \mathrm{v})$ of the mixed methanotrophic culture and $97 \%(\mathrm{v} / \mathrm{v})$ of diluted ammonium mineral salt (dAMS). The medium contained per liter, $15.28 \mathrm{~g} \mathrm{MgSO}_{4} \cdot 7 \mathrm{H}_{2} \mathrm{O}, 6.64 \mathrm{NH}_{4} \mathrm{Cl}, 2.292$ $\mathrm{CaCl}_{2} \cdot 2 \mathrm{H}_{2} \mathrm{O}, 0.5 \mathrm{~mL}$ of $0.1 \%$ (w/v) FeNaEDTA solution, $71.7 \mathrm{~g} \mathrm{Na}_{2} \mathrm{HPO}_{4} \cdot 12 \mathrm{H}_{2} \mathrm{O}, 38.2 \mathrm{~g} \mathrm{KH}_{2} \mathrm{PO}_{4}$ and $1.0 \mathrm{~mL}$ of trace elements solution. Flushing with pure $\mathrm{N}_{2}$ was performed to ensure anaerobic conditions. The seed culture was cultivated at $25{ }^{\circ} \mathrm{C}$ and $150 \mathrm{rpm}$ using a shaken incubator. Pure $\mathrm{CH}_{4}$ was provided as the sole carbon source and oxygen $\left(\mathrm{O}_{2} \geq 99.5 \%\right)$ was injected for oxidation. The gases were added until reaching an overpressure of 0.5 bar measured with a manometer.

\subsection{Batch cultivation at serum bottles}

Three sets of batch fermentations were carried out. First, a set of batch bottles was prepared in order to define the optimal $\mathrm{CH}_{4}: \mathrm{O}_{2}$ ratio to grow the mixed methanotrophic culture. For bacterial aerobic methane oxidation, a $\mathrm{CH}_{4}: \mathrm{O}_{2}$ ratio of $1: 2(\mathrm{v} / \mathrm{v})$ (i.e. 33.3:66.7 in the headspace) is suggested in the literature (Baesman et al., 2015; Steinle et al., 2017). Excess or limitation of $\mathrm{CH}_{4}$ can accelerate or hinder microbial growth of mixed cultures and thus, affect the quality of the produced 
microbial protein. Thus, three different volumetric $\mathrm{CH}_{4}: \mathrm{O}_{2}$ ratios were examined: 30:70, 35:65 and 40:60. The 33.3:66.7 ratio was used as control for comparisons based on:

$\mathrm{CH}_{4}+2 \mathrm{O}_{2} \rightarrow \mathrm{CO}_{2}+2 \mathrm{H}_{2} \mathrm{O}$

The consumption of gases was monitored and the headspace was daily refilled with fresh mixture of $\mathrm{CH}_{4}$ and $\mathrm{O}_{2}$. As a source of micro- and macro-nutrients, the effluent from a biogas reactor fed with municipal biowaste was used. Initially, the digestate was centrifuged to separate solid and liquid fractions; then, the supernatant was filtered and sterilized to avoid contamination. Before usage, the centrifuged-filtered digestate was diluted to $28 \mathrm{mg}-\mathrm{NH}_{4} / \mathrm{L}$ to be consistent with the nitrogen content of dAMS medium.

Subsequently, a second experimental set was conducted in order to explore the possibility of complete utilization of $\mathrm{AD}$ process effluent streams. For this purpose, raw biogas -produced from the same reactor that provided the $\mathrm{AD}$ effluent -was used as a $\mathrm{CH}_{4}$ source; instead of synthetic $\mathrm{CH}_{4}$ that was used in the first test. The detailed biogas composition $\left(\mathrm{CH}_{4}: \mathrm{CO}_{2}: \mathrm{H}_{2} \mathrm{~S}\right)$ was determined in order to calculate the amount of biogas that should be added in order to replace the synthetic-based $\mathrm{CH}_{4}$ with biogas-based $\mathrm{CH}_{4}$. Then, the appropriate amount of $\mathrm{O}_{2}$ was added to reach the targeted $\mathrm{CH}_{4}: \mathrm{O}_{2}$ ratio in the headspace. Finally, a third set of batch reactors was prepared to evaluate the effect of $\mathrm{H}_{2} \mathrm{~S}$, adding different concentrations (i.e. 500, 1000, 5000 and $10000 \mathrm{ppm}$ ) that can be found in raw biogas (Angelidaki et al., 2018). All batch tests were conducted in triplicates and under the same conditions as the methanotrophic seed culture cultivation. Always 3\% (v/v) of exponentially growing inoculum was used.

\subsection{Scaled-up operation}

A lab-scale continuously stirred fermenter with a total and working volume of 2.35 and $1.50 \mathrm{~L}$, respectively, was used to evaluate the cultivation of methanotrophs at larger scale. Pure methane 
and oxygen at volumetric ratio of 40:60 were supplied to the fermenter through a perforated marprene tube of numerous customized passages of $0.3 \mathrm{~mm}$ diameter. The gas mixture was collected from separate streams of compressed gases. The headspace of fermenter was connected to a 5.0 L gasbag to provide extra gas phase. Initially, the fermenter was filled with centrifugedfiltered digestate, inoculated with $3 \%(\mathrm{v} / \mathrm{v})$ seed and then, was operated at batch mode i.e. no inflow of growing medium and outflow of working volume were applied, recirculating the gas stream to increase the concentration of methanotrophs, while preventing them from washing out. When growth ceased, the dilution rate was set to $0.25 \mathrm{~d}^{-1}$ feeding the same anaerobic digestate as the batch tests. The dilution rate was gradually increased to 0.33 and $0.55 \mathrm{~d}^{-1}$ after passing through two fermenter volumes of digestate at each dilution rate (i.e. two hydraulic retention times, HRTs). Samples from fermenter effluent were collected to determine $\mathrm{pH}, \mathrm{OD}_{660}$, dry matter (DM) and ammonium $\left(\mathrm{NH}_{4}\right)$. The quantity of produced methanotrophs $(\mathrm{g}-\mathrm{DM} / \mathrm{L})$ was calculated through the relationship between dry cell weight and $\mathrm{OD}_{660} . \mathrm{NH}_{4}{ }^{+}$assimilation from the mixed methanotrophic consortium was calculated (g-DM/g-NH$)$. Additionally, amino acid profile of the methanotrophic culture was conducted to assess biomass suitability as animal feed. Furthermore, the volumetric gas consumption and the alternations of gas composition in gas phase were monitored to define microbial yield based on consumed methane (g-DM/g- $\left.\mathrm{CH}_{4}\right)$.

\subsection{Microbial analysis}

Triplicate samples of $20 \mathrm{~mL}$ were collected from batch fermenter fed with $\mathrm{CH}_{4}: \mathrm{O}_{2}$ mixture at 40:60 and biogas digestate at the exponential growth phase. Genomic DNA was isolated and purified using the PowerSoil ${ }^{\circledR}$ DNA Isolation Kit (QIAGEN Bioinformatics, Germany) with minor modifications as previously described (Bassani et al., 2015). The quality and quantity of DNA extracts were measured with NanoDrop (Thermo Scientific). The V4 region of microbial 16S rRNA genes was amplified using 515F/806R primers and sequenced by Illumina MiSeq platform. The raw 
reads were deposited in Sequence Read Archive (SRA) database (http://www.ncbi.nlm.nih.gov/sra) with accession number PRJNA543037. CLC Workbench software (V.8.0.2) was used for 16S rRNA gene sequencing analysis using the Microbial genomics module plug in (QIAGEN) based on (Kougias et al., 2017). The raw data were first trimmed using the default parameters of CLC software and Operational taxonomic unit (OTU) clustering was performed at 97\% similarity. OTUs phylogenetic assignment was performed with multiple sequence alignment of fixed length trimmed (240 bp) sequences using MUSCLE software and Greengenes v13_5 database as reference. The most abundant OTUs were chosen for discussion and the taxonomical assignment of sequences was verified in comparison with NCBI 16S ribosomal RNA database using Megablast (Johnson et al., 2008).

\subsection{Analytical methods}

The $\mathrm{pH}, \mathrm{DM}$ and ammonia were measured following the guidelines of standard methods for wastewater examination (APHA, 2005). Cell growth was monitored by measuring the optical density at $600 \mathrm{~nm}\left(\mathrm{OD}_{600}\right)$ using a spectrophotometer (Jenway Buch and Holm A/S 64050UV/vis). Before measurement, the treated digestate that was used as culture medium without methanotrophs was used for spectrophotometer calibration. Amino acid profile was determined via a high pressure liquid chromatography (Thermo Scientific Dionex UltiMate 3000 UHPLC, USA) based on D’Este et al. (2017). Methane consumption in the headspace of fermenters was monitored via a gaschromatograph (GC-TRACE 1310, Thermo Scientific) according to Khoshnevisan et al. (2018).

\subsection{Data analysis}

OriginPro 9.0.0 SR2 software (OriginLab Corporation, USA) was used to calculate descriptive statistics, mean values and standard deviations. Analysis of variance (ANOVA) with a Fisher's Least Significant Difference test (LSD, $\mathrm{p}<0.05)$ was followed to compare and reveal significant 
variations among treatments. In addition, the Levenberg-Marquardt algorithm was adopted to conduct the numerically fitting of experimental data obtained from the $\mathrm{H}_{2} \mathrm{~S}$ batch assays. The concentration that leads to fifty percent inhibition in microbial growth $\left(\mathrm{IC}_{50}\right)$ was defined.

\section{Results and discussion}

\subsection{Effect of gas feeding composition}

A comparative experimental set was initially conducted applying different gas compositions in order to determine the optimum $\mathrm{CH}_{4}: \mathrm{O}_{2}$ ratio. Results showed that the highest and lowest biomass production were $0.95 \pm 0.05$ and $0.36 \pm 0.02 \mathrm{~g}-\mathrm{DM} / \mathrm{L}$ at $40: 60$ and $30: 70 \mathrm{CH}_{4}: \mathrm{O}_{2}$ ratio, respectively (Fig. 1). Furthermore, significantly higher methanotrophic biomass was produced when the culture was cultivated at 40:60 $\mathrm{CH}_{4}: \mathrm{O}_{2}$ ratio (i.e.1.0:1.5) compared to the control operation (Fig. 1). Indeed, the experimentally optimum $\mathrm{CH}_{4}: \mathrm{O}_{2}$ ratio is close to the calculated stoichiometry:

$\mathrm{CH}_{4}+0.104 \mathrm{NH}_{3}+1.45 \mathrm{O}_{2} \rightarrow 0.52 \mathrm{CH}_{1.8} \mathrm{O}_{0.5} \mathrm{~N}_{0.2}+0.48 \mathrm{CO}_{2}+1.69 \mathrm{H}_{2} \mathrm{O}$

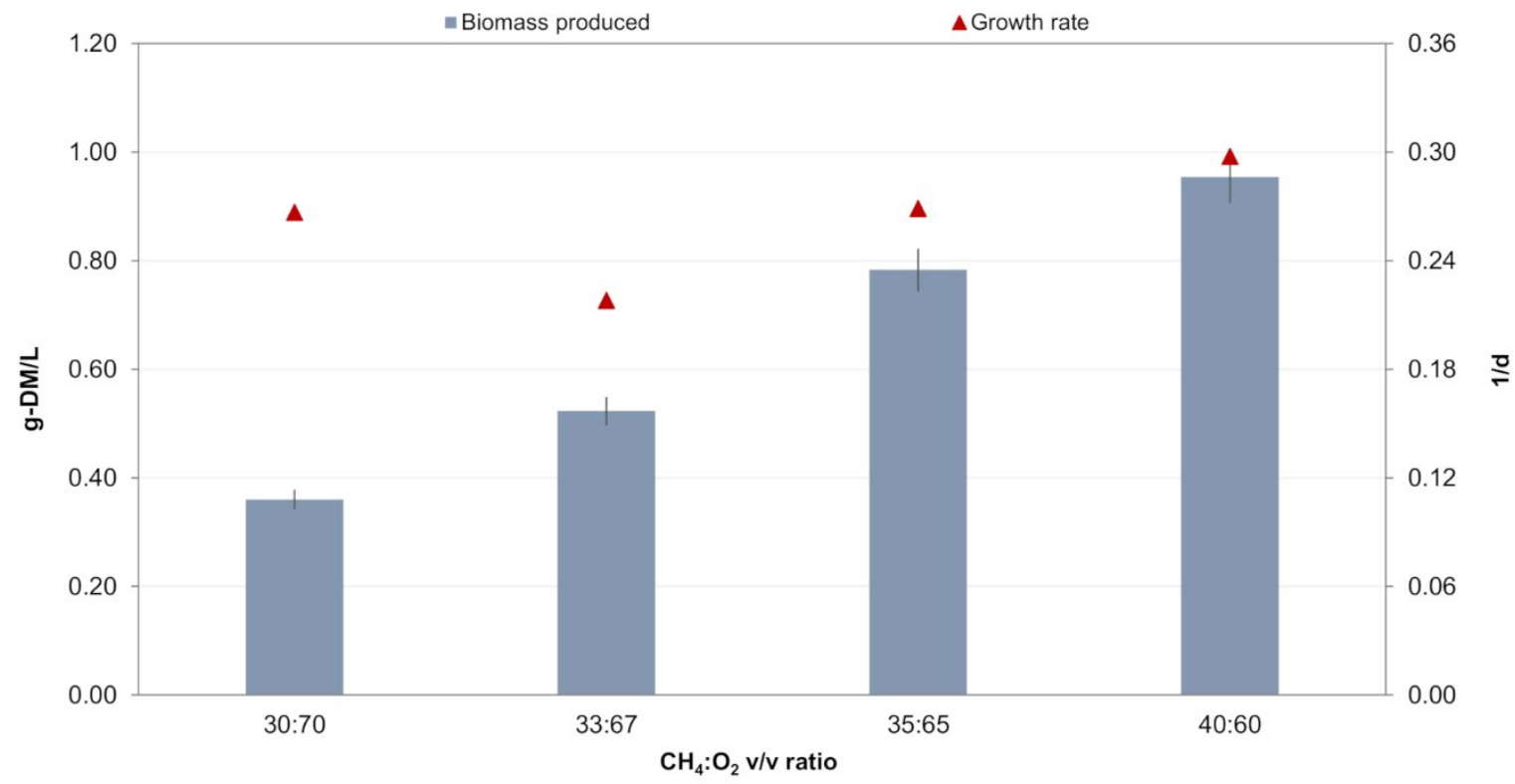

Fig. 1. Maximum biomass production and growth rate of mixed methanotrophic culture at different $\mathrm{CH}_{4}: \mathrm{O}_{2}$ ratios 
The changes in headspace composition, i.e., $\mathrm{CH}_{4}, \mathrm{O}_{2}$, and $\mathrm{CO}_{2}$, were monitored during the experiment in order to calculate the single cell protein (SCP) yield based on methane consumption ( $\left.\mathrm{Y}_{\mathrm{SCP} / \mathrm{CH} 4}\right)$. The results showed that the highest and lowest $\mathrm{Y}_{\mathrm{SCP} / \mathrm{CH} 4}$ were $0.73 \pm 0.04$ and $0.42 \pm$ $0.02 \mathrm{~g}-\mathrm{DM} / \mathrm{g}-\mathrm{CH}_{4}$ at 40:60 and 30:70 $\mathrm{CH}_{4}: \mathrm{O}_{2}$ ratio, respectively. Elevated $\mathrm{O}_{2}$ concentrations can negatively affect cell growth due to the accumulation of reactive oxygen species in the cell (Baez and Shiloach, 2014). At the end of the experiment, the $\mathrm{pH}$ of the cultivation medium for bottles fed with $\mathrm{CH}_{4}: \mathrm{O}_{2}$ at ratio of $40: 60$ and $30: 70$ were 5.78 and 6.12 , respectively. For bottles fed with $\mathrm{CH}_{4}: \mathrm{O}_{2}$ at ratio of $35: 65$ and $33: 67$, the final $\mathrm{pH}$ was 5.89 . During the fermentation, ammonia is uptaken by the methanotrophs (less than $10 \mathrm{mg}-\mathrm{NH}_{4} / \mathrm{L}$ at the end for all tests) and $\mathrm{CO}_{2}$ is dissociated into bicarbonate, in the liquid volume, leading to lower $\mathrm{pH}$. Thus, the most (i.e. 40:60) and less (i.e. 30:70) suitable gas composition are also aligned with the final $\mathrm{pH}$ values.

At the end of the incubation period, nitrate and nitrite were also measured. While methanotrophs can easily grow in both nitrate and ammonia ( $\mathrm{Hu}$ and $\mathrm{Lu}, 2015)$, nitrite can be significantly toxic and inhibit the microbial growth despite the fact that it can be oxidized by some methanotrophs (Nyerges et al., 2010). In the present study, only small amounts of $\mathrm{NO}_{3}^{-}(<0.80 \mathrm{mg} / \mathrm{L})$ and $\mathrm{NO}_{2}^{-}(<$ $0.15 \mathrm{mg} / \mathrm{L}$ ) were found in all experimental tests. Hence, a significant oxidation of $\mathrm{NH}_{4}{ }^{+}$to $\mathrm{NO}_{3}{ }^{-}$and $\mathrm{NO}_{2}^{-}$did not occur even at the bottles with surplus oxygen (i.e. 30:70). Thus, the effluent from a biogas reactor was directly and successfully used as a nitrogen rich stream to grow methanotrophs without triggering ammonia oxidation.

Regarding the microbial composition of the most efficient batch operation $\left(\mathrm{CH}_{4}: \mathrm{O}_{2}\right.$ mixture at 40:60), more than $70 \%$ of the microbial community can be represent by three bacteria OTUs (Fig. 2). Among them, Methylophilus sp. 1 was dominated the community with $44 \%$ relative abundance. Previous study indicated that bacteria belonging to Methylophilus contain high value amino acids, which was in accordance with amino acid standards for human nutrition and was comparable with 
high-quality fishmeal (Matassa et al., 2016). The high abundance of Methylophilus in the mixed culture suggests its potential to be used as food/feed supplements. As for the second dominant strain with $14 \%$ relative abundance, Methylomonas sp. 2 belonging to Gammaproteobacteria class was previously detected in mixed methanotrophic cultures grown for biotechnological applications (Jiang et al., 2016). Gammaproteobacteria are able to assimilate $\mathrm{CO}_{2}$ (Strong et al., 2015) and more specifically, it was previously indicated that similar Methylomonas strains were able to fixate $\mathrm{CO}_{2}$ (Puhar et al., 1983). Thus, the presence of Methylomonas in high abundance settles interesting the mixed culture to be tested for growing on real biogas. The third most abundant microbe, Comamonadaceae sp. 3, had a 13\% relative abundance and genera within Comamonadaceae family were previously detected in methane oxidation environments (Karwautz et al., 2018).

Comamonadaceae can oxidize ammonium under aerobic conditions (Bao and $\mathrm{Li}, 2017$ ) and thus, the usage of dAMS as growing medium could favour their establishment in the community.

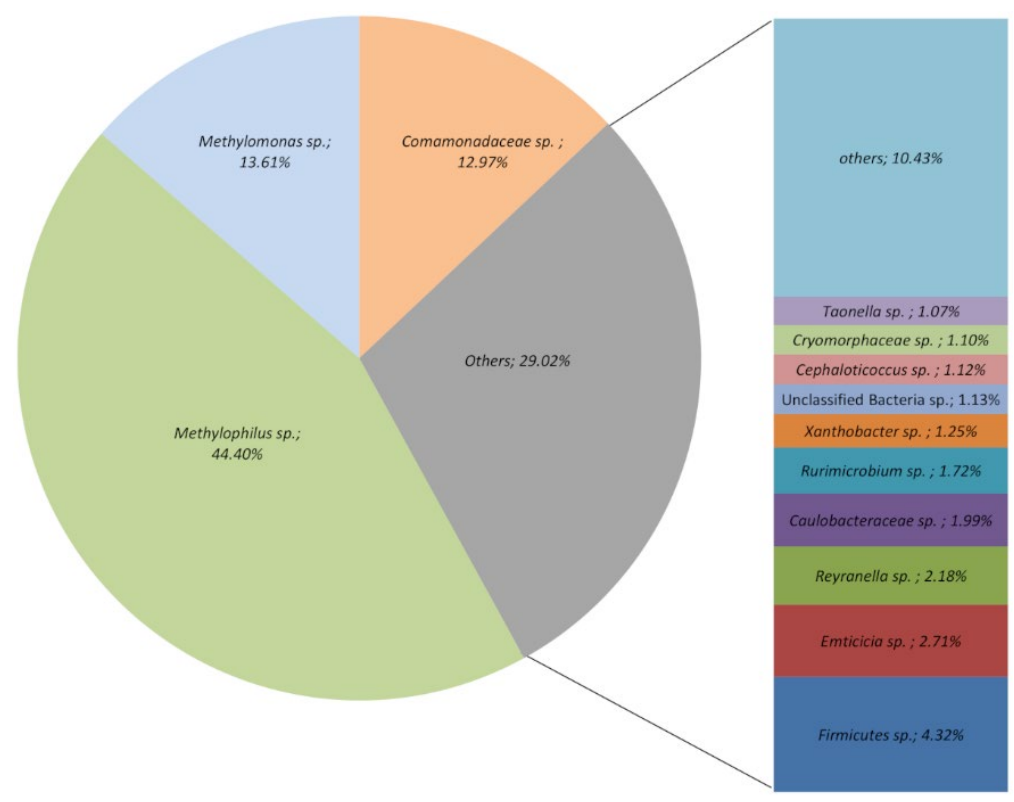

Fig. 2. Bacterial relative abundance (\%) of mixed methanotrophic culture (For interpretation of the references to colour in this figure legend, the reader is referred to the web version of this article.) 


\subsection{Effect of $\mathrm{H}_{2} \mathrm{~S}$ on mixed methanotrophic culture performance}

Subsequently, a second set of batch experiments was conducted to exploit the application of raw biogas as a source of methane. For this set, the gas in the headspace was kept at $40: 60 \mathrm{CH}_{4}: \mathrm{O}_{2}$ based on the initial tests. Monitoring of microbial growth showed that the bottles fed with biogas had markedly lower biomass production compared to the usage of pure methane (Fig. 3). More specifically, $0.61 \pm 0.09 \mathrm{~g}-\mathrm{DM} / \mathrm{L}$ was produced using biogas. In contrast, the microbial biomass production was $38.0 \%$ higher (i.e. $1.02 \pm 0.05 \mathrm{~g}$-DM/L) using pure methane and oxygen; which result is consistent with the outcome of the first test. Hence, it is indicated that the microbes were negatively affected by the addition of raw biogas.

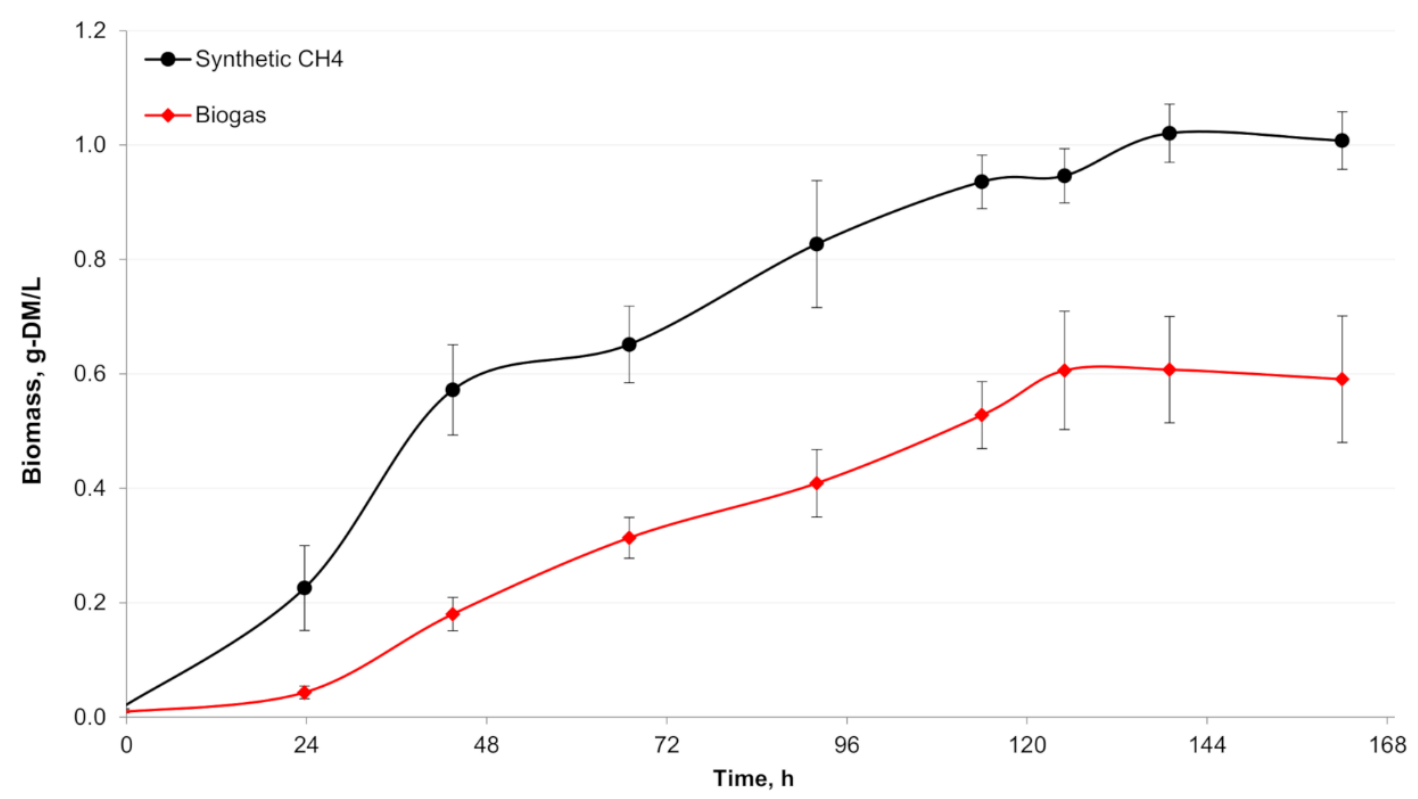

Fig. 3. Growth curves of mixed methanotrophic culture using synthetic methane and raw biogas at 40:60 $\mathrm{CH}_{4}: \mathrm{O}_{2}(\mathrm{v} / \mathrm{v})$ ratio

The used biogas consisted of $61.1 \% \mathrm{CH}_{4}, 38.9 \% \mathrm{CO}_{2}$ and $913 \mathrm{ppm}_{2} \mathrm{~S}$. Besides $\mathrm{CH}_{4}$, some methanotrophs can tolerate and in some cases assimilate $\mathrm{CO}_{2}$ for biomass generation (Chidambarampadmavathy et al., 2017). Contrary to the positive impact of the gasses in biogas, $\mathrm{H}_{2} \mathrm{~S}$ might exert adverse effect on growth of methylotrophs. The toxicity of $\mathrm{H}_{2} \mathrm{~S}$ in a number of 
microbial groups is well-known (Khoshnevisan et al., 2017). To elucidate the effect of $\mathrm{H}_{2} \mathrm{~S}$ in the used culture, a subsequent batch experiment was prepared at different concentrations (i.e. 0, 1000, $5000,10000 \mathrm{ppm}$ ) keeping the headspace at 40:60 $\mathrm{CH}_{4}: \mathrm{O}_{2}$. Results revealed a clear inhibition at $1000 \mathrm{ppm}$, as the biomass production was $44 \%$ lower than the bottles fed with synthetic $\mathrm{CH}_{4}$ in the absence of $\mathrm{H}_{2} \mathrm{~S}$ (Fig. 3). Furthermore, the toxic effect of $\mathrm{H}_{2} \mathrm{~S}$ was significantly more intense at 5000 and 10000 ppm in which the growth was hindered by 83 and 93\%, respectively. Based on Levenberg-Marquardt algorithm, the $\mathrm{IC}_{50}$ was calculated at $1376 \mathrm{ppm}$. Consequently, the computational method predicted that 913 ppm of $\mathrm{H}_{2} \mathrm{~S}$-amount that was available in the raw biogas -could lead to $37.6 \%$ inhibition. The calculated percentage is insignificantly different $(p>0.05)$ compared to the experimentally observed decrease (Fig. 3 and 4) and thus, adequate prediction accuracy was achieved.

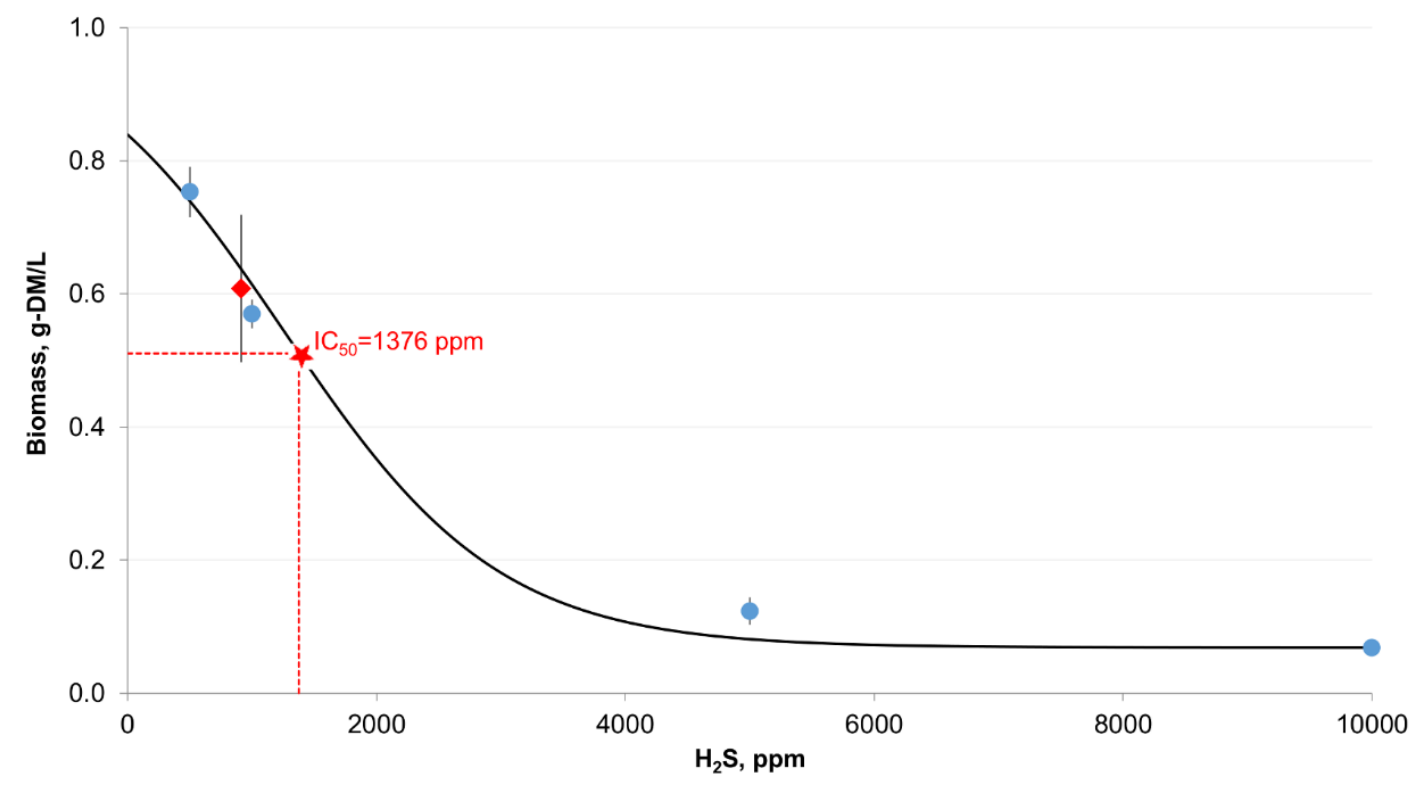

Fig. 4. Impact of $\mathrm{H}_{2} \mathrm{~S}$ at the growth of mixed methanotrophic culture. Blue circles indicate the biomass production at fermenters fed with pure gases, red rhombus the usage of raw biogas and red star the calculated $\mathrm{IC}_{50}$ 
Previously, a $\mathrm{H}_{2} \mathrm{~S}$ concentration higher than 500 ppm had an inhibitory effect to Methylocaldum sp. SAD2 growth; whereas at $1000 \mathrm{ppm} 44$ to $60 \%$ inhibition was provoked and then, at concentrations above 3000 ppm an even more severe inhibition was observed (Zhang et al., 2016). In another study, methane oxidation was inhibited at $200 \mathrm{ppm}$ growing methanotrophs belonging to Methylocystis genus (Lee et al., 2011). Therefore, the extent of $\mathrm{H}_{2} \mathrm{~S}$ inhibition varies among different methanotrophic cultures. However, the microbial protein production using raw biogas is prone to failure due to the presence of $\mathrm{H}_{2} \mathrm{~S}$. Removal of $\mathrm{H}_{2} \mathrm{~S}$ from biogas is a rather established technology and especially, the microaerobic desulfurization has a high potential to remove the toxic gas (Khoshnevisan et al., 2017). Thus, biogas cleaning via air injection could be a way to remove $\mathrm{H}_{2} \mathrm{~S}$ before usage and in case that $\mathrm{O}_{2}$ is remaining after desulfurization, it could be utilized by the methane oxidizing bacteria. For the scale-up test, pure methane of high standard quality ( $>99.9 \%$ ) was used in order to avoid potential inhibition from $\mathrm{H}_{2} \mathrm{~S}$.

\subsection{Lab-scale fermentation}

During the start-up phase, the fermenter was operated at batch mode. Comparable performance with the initial tests was achieved, as the biomass production was $0.86 \pm 0.01 \mathrm{~g}-\mathrm{DM} / \mathrm{L}$ (Fig. 5). However, faster growth was observed at $1.5 \mathrm{~L}$ fermenter compared to the $100 \mathrm{~mL}$ serum bottles. Gas recirculation via the perforated tube improved the gas to liquid transfer compared to the operational conditions created by the shaken incubator for the batch tests. Indeed, the microbial yield based on methane was significantly higher compared to the batch tests during the entire experiment (Table 1)

After 94 hours of operation, the fermenter was operated at dilution rate of $0.25 \mathrm{~d}^{-1}$ and a slight drop of biomass production was observed during the first hours of operation. However, the fermenter stabilized relatively quickly and at steady-state conditions the microbial production was $0.60 \pm 0.01 \mathrm{~g}-\mathrm{DM} / \mathrm{L}$. While increasing the dilution rate to $0.33 \mathrm{~d}^{-1}$ the protein content remained 
unchanged (Table 1), biomass production was decreased to $0.44 \pm 0.01 \mathrm{~g}-\mathrm{DM} / \mathrm{L}$. Thus, the subsequent drops of biomass production indicated that a further increase could result in washout. Hence, a final increase of dilution rate to $0.5 \mathrm{~d}^{-1}$ was examined. Indeed, the biomass production of methanotrophic culture was further eliminated to $0.29 \pm 0.04 \mathrm{~g}-\mathrm{DM} / \mathrm{L}$, indicating a huge risk of complete washout in case that a further increase of dilution rate was followed. Despite the microbial growth elimination, the protein was relatively unchanged during the whole experimental period (Table 1).

Furthermore, to evaluate to nutritional status of the produced biomass, amino acids analysis was also conducted. The amino acid profile showed that the total protein was mainly composed of aspartic acid (5.4\%), glutamic acid (5.7\%), lysine (3.4\%), valine (3.6\%), leucine (3.9\%), histidine $(4.7 \%)$ and alanine (3.5\%). In addition, serine, glycine, isoleucine, phenylalanine and arginine were also detected but in lower concentrations $(<3 \%)$. Focusing on the amino acids detected in higher range, the presence of aspartic and glutamic acid is in accordance with Rasouli et al. (2018) -who explored the microbial protein production using pure Methylococcus capsulatus -and found that the two acids were the most dominant components. Moreover, the high concentration of lysine, valine, leucine and histidine is of high importance, as they are among the essential amino acids to be used as fishmeal (Moutinho et al., 2018). Alanine belongs to the non-essential group but it has positive impact to increase the intracellular muscle-buffering capacity of the organisms and thus, its presence can promote the growth (Hoffman et al., 2018). Based on the amino acid profile, the mixed methanotrophic culture has a suitable composition to be used in livestock nutrition.

Despite the promising results achieved in the present study, further improvements are needed to widely establish the methanotrophic SCP production for animal feed. At industrial environment, UNIBIO has developed fermentation technology based on a patented U-Loop fermenter to increase the mass transfer rate of $\mathrm{CH}_{4}$ from gas to liquid phase and produce more bacterial cells over time 
(Ritala et al., 2017). Hence, production of methanotrophic SCP from natural gas reaches volumetric productivity and production volume of $4 \mathrm{~kg}-\mathrm{DM} / \mathrm{m}^{3} / \mathrm{h}$ and 80000 ton-DM/L, respectively, (Matassa et al., 2016). Alternative reactor design, more efficient static mixers or novel gas diffusers can be examined for further technology development. In addition, challenges are derived from the high nucleic acid content of bacterial cells that leads to low digestibility and causes adverse impacts to kidney and bladder. To decrease the RNA content, improvements on downstream (i.e. recovery and purification) are mandatory and on this topic, heat treatment can stand as step of a complex process (Strong et al., 2015). Furthermore, the existed industrially scaled production plants are facing economic challenges due to their rely on natural gas (Pikaar et al., 2018). Hence, the technical advantage of biogas -herein presented as an alternative methane source -could contribute on succeeding the industrial production at economically competitive prices (Khoshnevisan et al., 2019). Similarly, the replacement of the energy demanding reactive $N$ from Haber-Bosch process with inexpensive N-rich digestate can further improve economic feasibility. Hence, the complete valorisation of gaseous and liquid AD effluent streams is an attractive example of circular bioeconomy for real life applications.

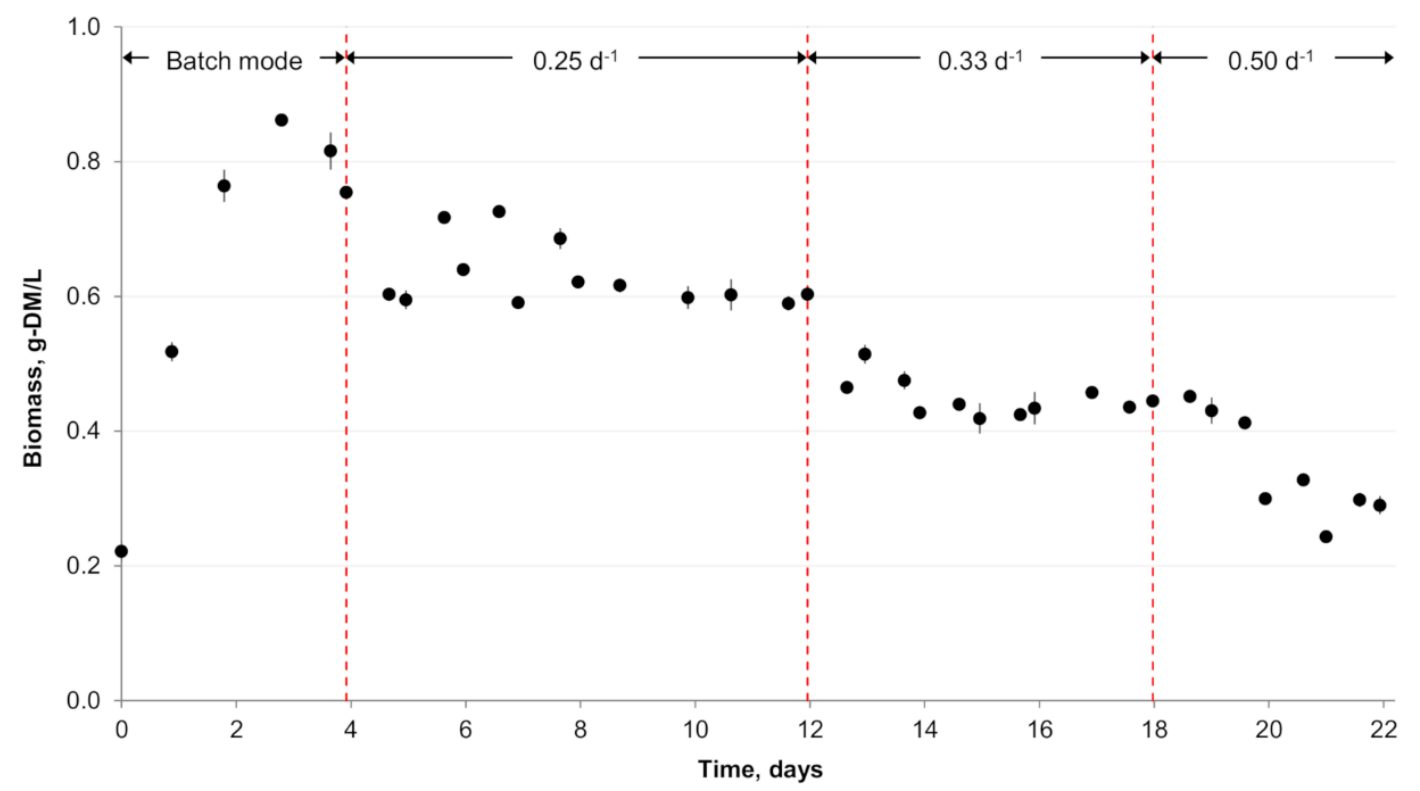


Fig. 5. Cultivation of mixed methanotrophic culture using pure $\mathrm{CH}_{4}$ and digestate at a lab-scale fermenter

Table 1. Biomass yield based on $\mathrm{CH}_{4}, \mathrm{NH}_{4}$ and protein content

\begin{tabular}{lccc}
\hline $\begin{array}{l}\text { Dilution rate, } \\
\mathbf{d}^{-\mathbf{1}}\end{array}$ & $\begin{array}{c}\mathbf{Y S C P}_{\mathbf{S C H} 4}, \\
\text { g-DM/g-CH4 }\end{array}$ & $\begin{array}{c}\mathbf{Y}_{\mathbf{N H} 4}, \\
\text { g-DM/g-NH4 }\end{array}$ & $\begin{array}{c}\text { Protein, } \\
\text { \% }\end{array}$ \\
\hline $\mathbf{0 . 2 5}$ & $0.79 \pm 0.14$ & $7.83 \pm 1.47$ & $40.91 \pm 0.84$ \\
$\mathbf{0 . 3 3}$ & $0.76 \pm 0.28$ & $8.46 \pm 1.07$ & $40.43 \pm 0.06$ \\
$\mathbf{0 . 5 0}$ & $0.66 \pm 0.01$ & $8.76 \pm 0.44$ & $41.11 \pm 0.02$ \\
\hline
\end{tabular}

\section{Conclusions}

The current research showed that the anaerobic digestion (AD) effluent can be a good source of nutrients to grow mixed methanotrophic cultures. Specifically, a relatively high amino acid content ( $>40 \%$ of dry weight) was produced by the Methylophilus enriched community. Feeding raw biogas at 40:60 $\mathrm{CH}_{4}: \mathrm{O}_{2}(\mathrm{v} / \mathrm{v})$ ratio to the community was attributed with lower biomass yield compared to the usage of pure methane; due to the presence of toxic $\mathrm{H}_{2} \mathrm{~S}$. Further research is needed in order to reveal the optimized growing conditions for mixed methanotrophic cultures grown in the effluents streams of AD process.

\section{Acknowledgement}

We acknowledge support from FUBAF project financed by the Danish EPA - MUDP (J.nr. Mst11700508). The authors thank Esben Frimann Jensen and Jacob Gavnholt Dueholm for assistance with experimental works conducted in the study.

\section{References}

Angelidaki, I., Treu, L., Tsapekos, P., Luo, G., Campanaro, S., Wenzel, H., Kougias, P.G., 2018. Biogas upgrading and utilization: Current status and perspectives. Biotechnol. Adv. 0-1.

APHA, 2005. Standard Methods for the Examination of Water and Wastewater. American Public Health Association, Washington, DC, USA. 
Baesman, S., Miller, L., Wei, J., Cho, Y., Matys, E., Summons, R., Welander, P., Oremland, R., 2015. Methane Oxidation and Molecular Characterization of Methanotrophs from a Former Mercury Mine Impoundment. Microorganisms 3, 290-309.

Baez, A., Shiloach, J., 2014. Effect of elevated oxygen concentration on bacteria, yeasts, and cells propagated for production of biological compounds. Microb. Cell Fact. 13. https://doi.org/10.1186/s12934-014-0181-5

Bao, P., Li, G.X., 2017. Sulfur-Driven Iron Reduction Coupled to Anaerobic Ammonium Oxidation. Environ. Sci. Technol. 51, 6691-6698.

Bassani, I., Kougias, P.G., Treu, L., Angelidaki, I., 2015. Biogas Upgrading via Hydrogenotrophic Methanogenesis in Two-Stage Continuous Stirred Tank Reactors at Mesophilic and Thermophilic Conditions. Environ. Sci. Technol. 49, 12585-12593.

Cantera, S., Lebrero, R., García-Encina, P.A., Muñoz, R., 2016. Evaluation of the influence of methane and copper concentration and methane mass transport on the community structure and biodegradation kinetics of methanotrophic cultures. J. Environ. Manage. 171, 11-20.

Chidambarampadmavathy, K., Karthikeyan, O.P., Huerlimann, R., Maes, G.E., Heimann, K., 2017. Responses of mixed methanotrophic consortia to variable $\mathrm{Cu} 2+/ \mathrm{Fe} 2+$ ratios. J. Environ. Manage. 197, 159-166.

D’Este, M., Alvarado-Morales, M., Angelidaki, I., 2017. Laminaria digitata as potential carbon source in heterotrophic microalgae cultivation for the production of fish feed supplement. Algal Res. 26, 1-7.

Foley, J.A., Ramankutty, N., Brauman, K.A., Cassidy, E.S., Gerber, J.S., Johnston, M., Mueller, N.D., O'Connell, C., Ray, D.K., West, P.C., Balzer, C., Bennett, E.M., Carpenter, S.R., Hill, J., Monfreda, C., Polasky, S., Rockström, J., Sheehan, J., Siebert, S., Tilman, D., Zaks, D.P.M., 2011. Solutions for a cultivated planet. Nature 478, 337-342.

Haraldsen, T.K., Andersen, U., Krogstad, T., Sørheim, R., 2011. Liquid digestate from anaerobic treatment of source-separated household waste as fertilizer to barley. Waste Manag. Res. 29.

Hoffman, J.R., Varanoske, A., Stout, J.R., 2018. Effects of $\beta$-Alanine Supplementation on Carnosine Elevation and Physiological Performance. Adv. Food Nutr. Res. 84, 183-206.

$\mathrm{Hu}, \mathrm{A} ., \mathrm{Lu}, \mathrm{Y} ., 2015$. The differential effects of ammonium and nitrate on methanotrophs in rice field soil. Soil Biol. Biochem. 85, 31-38.

Jiang, H., Duan, C., Jiang, P., Liu, M., Luo, M., Xing, X.H., 2016. Characteristics of scale-up fermentation of mixed methane-oxidizing bacteria. Biochem. Eng. J. 109, 112-117.

Kalyuzhnaya, M.G., Yang, S., Rozova, O.N., Smalley, N.E., Clubb, J., Lamb, A., Gowda, G.A.N., Raftery, D., Fu, Y., Bringel, F., Vuilleumier, S., Beck, D.A.C., Trotsenko, Y.A., Khmelenina, V.N., Lidstrom, M.E., 2013. Highly efficient methane biocatalysis revealed in a methanotrophic bacterium. Nat. Commun. 4.

Karwautz, C., Kus, G., Stöckl, M., Neu, T.R., Lueders, T., 2018. Microbial megacities fueled by methane oxidation in a mineral spring cave. ISME J. 12, 87-100. 
Khoshnevisan, B., Tsapekos, P., Alfaro, N., Díaz, I., Fdz-Polanco, M., Rafiee, S., Angelidaki, I., 2017. A review on prospects and challenges of biological H2S removal from biogas with focus on biotrickling filtration and microaerobic desulfurization. Biofuel Res. J. 4, 741-750.

Khoshnevisan, B., Tsapekos, P., Alvarado-Morales, M., Angelidaki, I., 2018. Process performance and modelling of anaerobic digestion using source-sorted organic household waste. Bioresour. Technol. 247, 486-495.

Khoshnevisan, B., Tsapekos, P., Zhang, Y., Valverde-Pérez, B., Angelidaki, I., 2019. Urban biowaste valorization by coupling anaerobic digestion and single cell protein production. Bioresour. Technol. 290, 121743. https://doi.org/10.1016/j.biortech.2019.121743

Kougias, P.G., Treu, L., Benavente, D.P., Boe, K., Campanaro, S., Angelidaki, I., 2017. Ex-situ biogas upgrading and enhancement in different reactor systems. Bioresour. Technol. 225, 429437.

Lantz, M., 2012. The economic performance of combined heat and power from biogas produced from manure in Sweden - A comparison of different CHP technologies. Appl. Energy 98, 502511.

Lee, E.H., Yi, T., Moon, K.E., Park, H., Ryu, H.W., Cho, K.S., 2011. Characterization of methane oxidation by a methanotroph isolated from a landfill cover soil, South Korea. J. Microbiol. Biotechnol. 21, 753-756.

Matassa, S., Batstone, D.J., Hülsen, T., Schnoor, J., Verstraete, W., 2015. Can direct conversion of used nitrogen to new feed and protein help feed the world? Environ. Sci. Technol. 49, 52475254.

Matassa, S., Boon, N., Pikaar, I., Verstraete, W., 2016. Microbial protein: future sustainable food supply route with low environmental footprint. Microb. Biotechnol. 9, 568-575.

Moutinho, S., Martínez-Llorens, S., Tomás-Vidal, A., Jover-Cerdá, M., Oliva-Teles, A., Peres, H., 2018. Meat and bone meal as partial replacement for fish meal in diets for gilthead seabream (Sparus aurata) juveniles: Growth, feed efficiency, amino acid utilization, and economic efficiency. Aquaculture 768, 271-277.

Nyerges, G., Han, S.K., Stein, L.Y., 2010. Effects of ammonium and nitrite on growth and competitive fitness of cultivated methanotrophic bacteria. Appl. Environ. Microbiol. 76, 56485651 .

Pikaar, I., de Vrieze, J., Rabaey, K., Herrero, M., Smith, P., Verstraete, W., 2018. Carbon emission avoidance and capture by producing in-reactor microbial biomass based food, feed and slow release fertilizer: Potentials and limitations. Sci. Total Environ. 644, 1525-1530. https://doi.org/10.1016/j.scitotenv.2018.07.089

Puhar, E., Lorencez, I., Fiechter, A., 1983. Influence of partial pressure of oxygen and carbon dioxide on Methylomonas clara in continuous culture. Eur. J. Appl. Microbiol. Biotechnol. 18, $131-134$.

Rafiee, S., Khoshnevisan, B., Mohammadi, I., Aghbashlo, M., Mousazadeh, H., Clark, S., 2016. Sustainability evaluation of pasteurized milk production with a life cycle assessment approach: 
An Iranian case study. Sci. Total Environ. 562, 614-627.

Rasouli, Z., Valverde-Pérez, B., D’Este, M., De Francisci, D., Angelidaki, I., 2018. Nutrient recovery from industrial wastewater as single cell protein by a co-culture of green microalgae and methanotrophs. Biochem. Eng. J. 134, 129-135.

Ritala, A., Häkkinen, S.T., Toivari, M., Wiebe, M.G., 2017. Single cell protein-state-of-the-art, industrial landscape and patents 2001-2016. Front. Microbiol. 8. https://doi.org/10.3389/fmicb.2017.02009

Steinle, L., Maltby, J., Treude, T., Kock, A., Bange, H.W., Engbersen, N., Zopfi, J., Lehmann, M.F., Niemann, H., 2017. Effects of low oxygen concentrations on aerobic methane oxidation in seasonally hypoxic coastal waters. Biogeosciences 14, 1631-1645.

Strong, P.J., Xie, S., Clarke, W.P., 2015. Methane as a resource: Can the methanotrophs add value? Environ. Sci. Technol. 49, 4001-4018.

Styles, D., Adams, P., Thelin, G., Vaneeckhaute, C., Chadwick, D., Withers, P.J.A., 2018. Life Cycle Assessment of Biofertilizer Production and Use Compared with Conventional Liquid Digestate Management. Environ. Sci. Technol. 52, 7468-7476.

UNG Assembly, 2015. Transforming our world: the 2030 Agenda for Sustainable Development.

Zhang, W., Ge, X., Li, Y.F., Yu, Z., Li, Y., 2016. Isolation of a methanotroph from a hydrogen sulfide-rich anaerobic digester for methanol production from biogas. Process Biochem. 51, 838-844. 